\title{
A MOLECULAR METHOD FOR A QUALITATIVE ANALYSIS OF POTENTIALLY CODING SEQUENCES OF DNA
}

\author{
CHRISTOFFERSEN, M. L., ${ }^{1}$ ARAÚJO, M. E. ${ }^{2}$ and MOREIRA, M. A. M. ${ }^{3}$ \\ ${ }^{1}$ Departamento de Sistemática e Ecologia, Universidade Federal da Paraíba, CEP 58059-900, \\ João Pessoa, PB, Brazil \\ ${ }^{2}$ Departamento de Engenharia de Pesca, Universidade Federal do Ceará, Campus do Pici, Bloco 827, \\ CEP 60455-760, Fortaleza, CE, Brazil \\ ${ }^{3}$ Divisão de Genética, Instituto Nacional de Câncer, Praça da Cruz Vermelha, 23, CEP 20230-130, \\ Rio de Janeiro, RJ, Brazil \\ Correspondence to: Martin Lindsey Christoffersen, Departamento de Sistemática e Ecologia, Universidade Federal \\ da Paraíba, CEP 58059-900, João Pessoa, PB, Brazil, e-mail: mlchrist@ dse.ufpb.br \\ Received February 4, 2003 - Accepted April 30, 2003 - Distributed August 31, 2004
}

(With 2 figures)

\begin{abstract}
Total sequence phylogenies have low information content. Ordinary misconceptions are that character quality can be ignored and that relying on computer algorithms is enough. Despite widespread preference for a posteriori methods of character evaluation, a priori methods are necessary to produce transformation series that are independent of tree topologies. We propose a stepwise qualitative method for analyzing protein sequences. Informative codons are selected, alternative amino acid transformation series are analyzed, and most parsimonious transformations are hypothesized. We conduct four phylogenetic analyses of philodryanine snakes. The tree based on all nucleotides produces least resolution. Trees based on the exclusion of third positions, on an asymmetric step matrix, and on our protocol, produce similar results. Our method eliminates noise by hypothesizing explicit transformation series for each informative protein-coding amino acid. This approaches qualitative methods for morphological data, in which only characters successfully interpreted in a phylogenetic context are used in cladistic analyses. The method allows utilizing character information contained in the original sequence alignment and, therefore, has higher resolution in inferring a phylogenetic tree than some traditional methods (such as distance methods).
\end{abstract}

Key words: molecular cladistics, qualitative approach, a priori method, mitochondrial cytochrome b gene, Serpentes.

\section{RESUMO}

\section{Um método molecular para análises qualitativas de seqüiências potencialmente codificadoras de DNA}

Filogenias baseadas em seqüências totais têm baixo conteúdo informativo. Erros comuns são acreditar que a qualidade dos caracteres pode ser ignorada e que é suficiente confiar nos algoritmos computacionais. Apesar de ampla preferência por métodos a posteriori para a avaliação de caracteres, métodos $a$ priori tornam-se necessários para produzir séries de transformação independentes das topologias das árvores. Propomos um método qualitativo passo a passo para analisar sequiências de proteínas. Codons informativos são selecionados, séries de transformação alternativas de aminoácidos são analisadas e as transformações mais parcimoniosas são hipotetizadas. Conduzimos quatro análises filogenéticas em cobras Phylodrininae. A árvore baseada em todos os nucleotídeos produz a menor resolução. Árvores baseadas na exclusão das terceiras posições, numa matriz de passos assimétrica, e em nosso protocolo de análise produzem resultados similares. Nosso método elimina ruído ao hipotetizar séries de transformação explícitas para 
cada aminoácido informativo para a codificação de proteínas. Essa abordagem se aproxima de métodos qualitativos para dados morfológicos, nos quais apenas caracteres interpretados com sucesso num contexto filogenético são usados em análises cladísticas. O método permite utilizar informação de caracteres contidos no alinhamento original da seqüência e, portanto, tem maior poder de resolução para inferir árvores filogenéticas que alguns métodos tradicionais (como métodos de distância).

Palavras-chave: cladística molecular, abordagem qualitativa, método a priori, gene mitocondrial citocromo b, Serpentes

\section{INTRODUCTION}

Phylogenetic systematics represents one of the fundamental branches of the biological sciences. We need stable and realistic biological systems based on the phylogeny of living organisms for effective communication among scientists, for teaching purposes, and for research (Wägele, 1999). Total sequence studies are known to produce phylogenies of low information content, although the signals may be sufficient to indicate relationships that are at least partly congruent with phylogenies based on morphological data (Dreyer \& Wägele, 2001).

DNA and amino acid sequences have been used for phylogenetic studies since 1967, with algorithms based on distance and parsimony methodologies (e.g., Fitch \& Margoliash, 1967; Fitch, 1971; Moore et al., 1973, 1976; Felsenstein, 1988; Swofford et al., 1996a; Li, 1997). Particularly, mitochondrial DNA sequences were largely used in phylogenetic approaches due to the development of the PCR methodology (Mullis et al., 1986) using "universal" primers (Kocher et al., 1989; Irwin et al., 1991).

The higher nucleotide substitution rate of mtDNA (Brown et al., 1979) leads to the employment of different methods aimed at reducing the noise present in data sets. These methods can be divided into two groups: (1) methods that eliminate characters or state changes (i.e., eliminating the third codon at all positions, considering only transversions at the third codon position, considering only transversions at all sites, or using the deduced amino acid sequences); and (2) methods that give different weights for state changes (weighted parsimony [Farris, 1969] and transversion parsimony [Swofford et al., 1996b]). The use of amino acid sequences employs alternative approaches considering the amino acid substitutions, or the minimal number of nucleotide substitutions necessary to change from one amino acid to another.

One of the logical mistakes common among cladists, particularly molecular systematists, is to believe that character quality can be ignored and that it is enough to rely on the algorithms of a computer program. So one of the important questions of molecular phylogeny involves exploring the information content of DNA sequences. Cladists prefer a posteriori methods of character evaluation, of which the most decisive test is overall congruence with other homologies (Patterson, 1988). But a priori methods of probability of homology that are not dependent on tree topology are also necessary for evaluating characters. The security for a hypothesis of homology increases with the degree of complexity and similarity of the compared structures (Remane, 1961). In molecular phylogeny, the analysis of larger portions of molecules than single nucleotides and amino acids may be interesting in this respect because they provide more complex characters more easily subject to quality assessments.

Several methods have been developed for the reconstruction of historical relationships among species and higher taxa ( $\mathrm{Li}, 1997)$. In the last decade, cladistic analyses have been dominated by molecular data, but in practice conspicuous contradictions occur between morphological and molecular data, and also within each class of characters (Wägele \& Wetzel, 1994; Dreyer \& Wägele, 2001).

Growing evidence suggests that phylogenies of animal phyla constructed by the analysis of $18 \mathrm{~S}$ rRNA sequences may not be as accurate as originally thought. Empirical results underscore the need for approaches of phylogenetic inference that go beyond simple site-by-site comparison of aligned sequences (Naylor \& Brown, 1998). Inaccuracies may occur in molecular phylogenies, based on sequence analyses of nucleotides, for a variety of generally recognized 
reasons: (1) ambiguous alignments (Lake, 1991; Wägele \& Stanjek, 1995; Winnepenninckx \& Backeljau, 1996); (2) lack of strong statistical support for important groupings; (3) results sensitive to and affected by the chosen representative groups for analyses (Wheeler, 1990; Lecointre et al., 1993); (4) statistical inconsistency (as the amount of data increases, so does the statistical support for an incorrect phylogenetic tree); (5) long branch attraction; (6) the symplesiomorphy trap (Wägele, 1999).

The amino acid sequences of proteins may be more immune to the problems of long branch attraction. Furthermore, protein-coding genes constitute a much larger proportion of the genome than RNAcoding genes. Thus, it is likely that protein sequences will eventually become a major source of data for inferring phylum-level relationships (Goldman \& Yang, 1994), especially with the growing number of animal genome projects (Abouheif et al., 1998; McHugh, 1998; Maley \& Marshall, 1998; Giribet \& Wheeler, 1999). Wägele (1999) has recognized that errors in phylogenetic inference can occur at three different levels: species sampling, character sampling, and selection of tree constructing algorithms.

Our aim in this paper is to provide a new qualitative method for phylogenetic analyses of sequence data. The proposed method considers those alterations in nucleotides that effectively result in corresponding changes in amino acids. To accomplish this, we analyse a priori transformation series that are considered to be most parsimonious within an evolutionary context.

\section{MATERIAL AND METHODS}

\section{Phylogenetic analysis}

The sequence data of DNA was analyzed using the program PAUP 4.0 (Phylogenetic Analysis Using Parsimony) (Swofford, 1998) with branch and bound to obtain the most parsimonious trees (Fig. 1a, b). A bootstrap analysis was conducted with 1,000 replications. These data were analyzed using two distinct treatments: complete sequences and sequences without third positions.

\section{Our proposed method for a qualitative analysis of sequence data}

The method presented herein compares protein sequences for the analysis of transformation series of amino acids (Table 1), starting with the analysis of their respective codons. In other words, beyond the simple consideration of final DNA sequences as presented by many computerized cladistic programs, our method considers possible transformations and number of evolutionary steps that may occur in each series.

There are three main types of transformation series: (1) when a single substitution of a nucleotide is responsible for the direct passage from the plesiomorphic to the apomorphic character condition; (2) when the passage from the plesiomorphic to the apomorphic condition implies one or more intermediate codons synonymous to one of these two terminal amino acids; (3) when the passage from a plesiomorphic to an apomorphic condition implies the formation of one or more intermediary amino acids that are distinct from terminal amino acids.

\section{Criteria for tree construction using qualitative information from sequence data}

Criteria used to construct our stepwise matrix (Table 1) and the asymmetric step matrix for nonsynonymous nucleotide substitutions (Appendices $1,2)$ are based on the vertebrate mitochondrial genetic code. To construct a cladogram based on the qualitative information contained in sequence data, we consider the following situations for the mitochondrial DNA genetic code:

(1) Nucleotide replacements that result in single amino acid substitutions were given priority. Synonymous replacements between homologous codons were not considered as producing extra steps in the analyses.

Example: Outgroup: $\mathrm{ATT}^{\mathrm{Il}}$; ingroup: $\mathrm{ACC}^{\mathrm{Thr}}$. Possible parsimonious transformation series: (1) $\mathrm{ATT}^{\mathrm{lle}} \rightarrow \mathrm{ATC}^{\mathrm{ll}} \rightarrow \mathrm{ACC}^{\mathrm{Thr}}$; (2) $\mathrm{ATT}^{\mathrm{lle}} \rightarrow \mathrm{ACT}^{\mathrm{Thr}} \rightarrow$ $\mathrm{ACC}^{\mathrm{Thr}}$. Both cases involve two transitions in the second and third bases, passing by an intermediary codon.

(2) For Leucine and Serine, which were coded by six different codons each, the codons UUR ${ }^{\text {Leu, }}$, $\mathrm{CUC}^{\mathrm{Leu}}, \mathrm{AGY}^{\mathrm{Ser}}$, and $\mathrm{UCX}^{\text {Ser }}$ were considered to be different character states.

Example: All ingroups share Leucine, but some taxa have codon CTA and others TTA. We will obtain two different clades, based on the two distinct codons.

(3) Codons present or absent at homologous positions were considered to reduce the number of steps to explain a topology.

Example: Outgroups: ATC ${ }^{\text {Ile }}$; ingroup: ATC ${ }^{\mathrm{Ile}}$, TTA $/ G^{\text {Leu }}$, and ATA $/ G^{\text {Met }}$. Possible parsimonious 
transformation series: (1) ATC ${ }^{\mathrm{Ile}} \rightarrow$ ATA/G ${ }^{\mathrm{Met}} \rightarrow$ TTA/ $\mathrm{G}^{\mathrm{Leu}}$, with two transversions in the first and third positions; (2) ATC $^{\text {le }} \rightarrow$ ATA $/ G^{\text {Met }}$ and $\mathrm{ATC}^{\text {lle }} \rightarrow$ TTC $^{\text {Phe }} \rightarrow$ TTA $/ G^{\mathrm{Leu}}$, with one transversion (in the third position) for Methionine, and two transversions (in first and third positions) for Leucine. The first series is more parsimonious for not implying in the appearance of an extra amino acid that is not present among the studied groups.

(4) Stop codons were excluded as intermediary or terminal character states.

Example: (1) $\mathrm{CGA}^{\mathrm{Arg}} \rightarrow \mathrm{AGA}$ (Stop code) $\rightarrow$ AGC/T ${ }^{\text {Ser. }}$. (2) $\mathrm{CGA}^{\mathrm{Arg}} \rightarrow \mathrm{CGT}^{\mathrm{Arg}} \rightarrow \mathrm{AGC} / \mathrm{T}^{\mathrm{Ser}}$. Both series have two transversions, in the first and third bases. We opt for the second series, because of the absence of a stop codon.

(5) Following the establishment of the most consistent synapomorphies, reversions will be considered if they reduce the total number of steps in a sequence.

\section{The asymmetric step matrix for non-synonymous substitutions}

In addition to this method, we constructed a matrix from an asymmetric step matrix (Appendices 1,2 ) based on the known vertebrate mitochondrial genetic code. This step matrix was implemented in PAUP 4.0 for the construction of cladograms (Fig. $1 \mathrm{c}, \mathrm{d})$ to test the consistency of our method.

To construct this step matrix, codons for the same amino acid that differ by a third base transversion must be coded as different character states, and codons for the same amino acid differing by a third base transition must be coded as a same character state. The six codons for Serine and Leucine are coded by three different symbols each (see Appendix 1).

The use of an asymmetrical step matrix may be justified by the following example: $\mathrm{CAY}^{\text {His }} \rightarrow$ GUX $^{\text {Val }}$ imply in two nucleotide substitutions, i.e., two steps. However, the reverse change, GUX ${ }^{\text {val }}$ $\mathrm{CAY}^{\text {His }}$, may involve two (GUY' $\rightarrow \mathrm{CAY}^{\text {His }}$ ) or three nucleotide substitutions (GUR ${ }^{\mathrm{Val}} \rightarrow \mathrm{CAY}^{\mathrm{His}}$ ). This matrix differs from previous symmetrical step matrices (Fitch \& Margoliash, 1967), which are based on the minimal number of nucleotide replacements necessary to explain an amino acid substitution. These symmetrical matrices do not consider the DNA codon sequences. Consequently, the amino acid substitutions $\mathrm{Val} \rightarrow \mathrm{His}$ or His $\rightarrow$ Val will involve only two nucleotide substitutions, as the third codon position is not taken into account. This step matrix was used in PAUP 4.0 with the option ALLSTATES, which considers all possible options for character states to be assigned to inner nodes (Swofford, 1998). The results obtained from the computerized analyses with PAUP 4.0 are compared with the cladogram constructed with the new qualitative method proposed herein (Fig. 2).

\section{RESULTS}

In this paper we have explored the quality of sequence data for phylogenetic inference. We propose an alternative approach (using an asymmetric step matrix) that considers nucleotide replacements that effectively lead to amino acid substitutions for the construction of phylogenies. Initially, it is necessary to construct a data set considering the codons deduced from nucleotide sequences. Thus, codons for the same amino acid that differ by transitions in the third codon position are considered the same character state. Using the vertebrate mitochondrial genetic code, as in our example, codons for Phenylalanine, UUU and UUC, are represented in the data set by the same symbol; codons for Proline CCU and CCC, or CCA and CCG are represented by two different symbols. The asymmetric step matrix for character state changes takes into account only nucleotide replacements that lead to amino acid substitutions. Exemplifying, a codon substitution from $\mathrm{CCY}^{\text {Pro }}$ to $\mathrm{CCR}^{\text {Pro }}$, or viceversa, receives the value 0 (zero steps) as there is no amino acid substitution; a substitution from $\mathrm{CCY}^{\mathrm{Pro}}$ to $\mathrm{UUY}^{\mathrm{Phe}}$ and from $\mathrm{UUY}^{\mathrm{Phe}}$ to $\mathrm{CCX}^{\mathrm{Pro}}$ receives the value 2 (two steps); and a substitution from $\mathrm{CCR}^{\text {Pro }}$ to $\mathrm{UUY}^{\text {Phe }}$ receives the value 3 (three steps).

Amino acids like Serine and Leucine, which are coded by six different codons (UCX/AGY and UUR/CUX, respectively) deserve special attention, as replacement of a codon by another could imply an intermediate amino acid (UCX ${ }^{\text {Ser }}$ to $\mathrm{AGY}^{\text {Ser }}$ would imply the intermediate codons $\mathrm{UGY}^{\mathrm{Cys}}$, UGR ${ }^{\mathrm{Tr}}$, AUY ${ }^{\text {Leu }}$, AUR $\left.{ }^{\mathrm{Met}}\right)$. Thus, the phylogenetic information comprised in these substitutions could be used, given the number of nucleotide substitutions necessary to change from one codon to another: from $\mathrm{UCX}^{\text {Ser }}$ to $\mathrm{AGY}^{\mathrm{Ser}}$, two or three steps, and from $\mathrm{AGY}^{\mathrm{Ser}}$ to $\mathrm{UCX}^{\mathrm{Ser}}$, two steps; from UUR ${ }^{\mathrm{Leu}}$ to CUX ${ }^{\mathrm{Leu}}$, one step, and from CUX ${ }^{\mathrm{Leu}}$ to $\mathrm{UUR}^{\mathrm{Leu}}$, one or two steps. 
a)

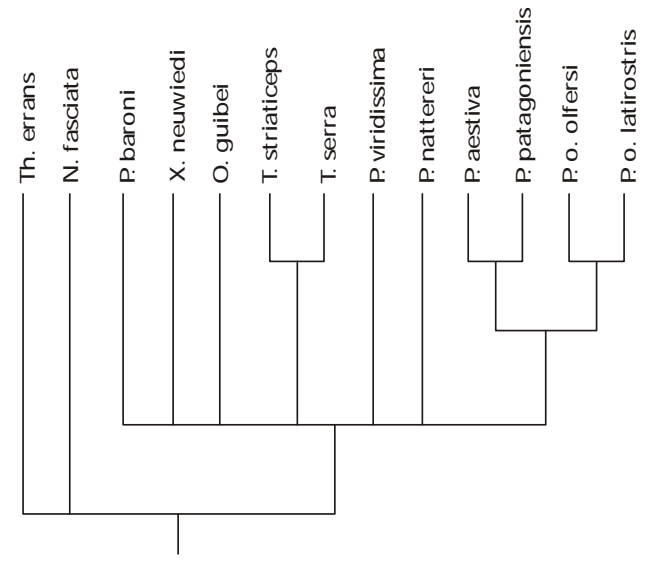

c)

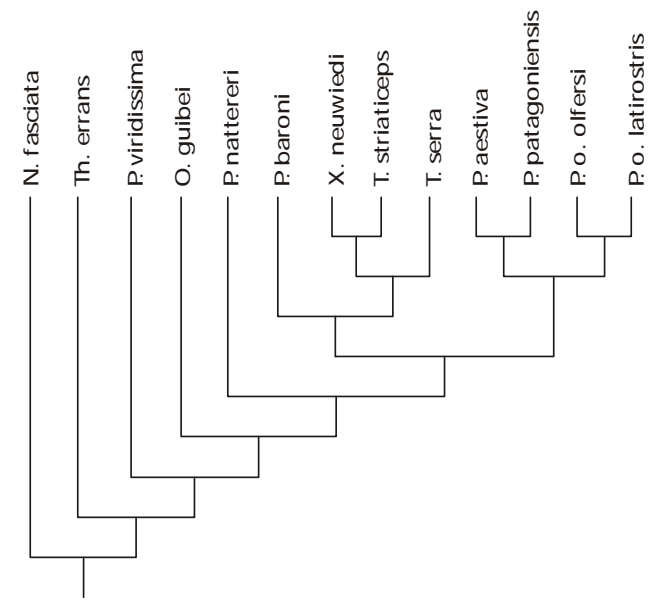

b)

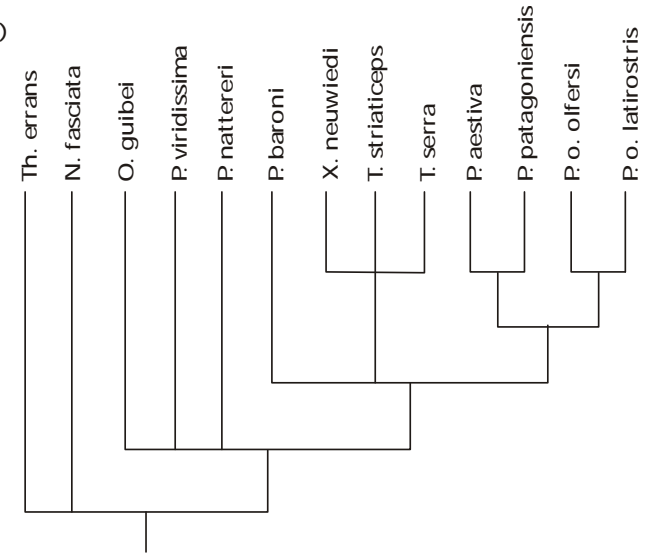

d)

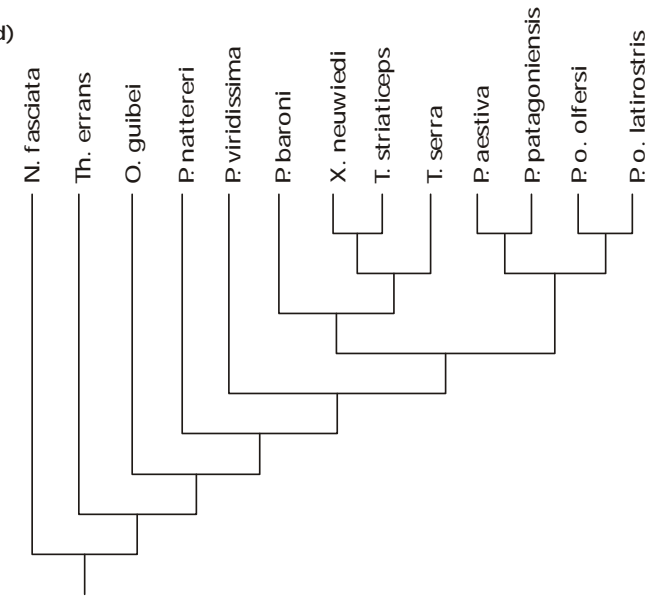

Fig. 1 - (a) Strict consensus of three equally parsimonious trees using complete sequences of nucleotides. Obtained with PAUP4.0 (length, 406, CI, 0.603); (b) strict consensus of four equally parsimonious trees using sequences of nucleotides without the third positions of codons. Obtained with PAUP 4.0 (length, 131, CI, 0.718). (c) and (d), the two most parsimonious trees obtained with the asymmetric step matrix (Appendix 3) in PAUP 4.0 (length 140). N, Nerodia; O, Oxyrhophus; o, olfersi; P, Philodryas; T, Tropidodryas; Th, Thamnophys; X, Xenodon.

When the analyses conducted by us are compared, it is interesting to note that the phylogeny based on all nucleotide positions (306 bases) results in the tree of least resolution (Fig. 1a). On the other hand, the tree based on the exclusion of third positions (Fig. $1 b)$ is similar to the phylogeny obtained with the application of our method (Fig. 2), but differs by its lesser resolution.

Philodryas viridissima is placed within the ingroup based on the most parsimonious transformation series according to our analysis (Fig. 2). Codon in sequence position number 10 (Table 1) was responsible for this relationship. The transformation series of codon 10 is also representative of our methodological approach. The outgroups have Alanine for codon 10, while the ingroups usually have Isoleucine, except for Tyrosine in Philodryas viridissima, and Valine in P. nattereri. The most parsimonious hypothesis for the transformation from Alanine to Isoleucine is through Valine. Consequently, P. nattereri must occupy a position that precedes the acquisition of Isoleucine in the evolution of xenodonthines. In the transformation 
series Alanine $\rightarrow$ Tyrosine (character 10 in Table 1), a Serine would be the necessary intermediary amino acid, but it is absent in all sampled taxa. As the alternative transformation from Isoleucine to Tyrosine occurred in our studied sample and reduced one required step in the analysis, this transformation is preferred over the alternative that requires an amino acid that does not exist in our sample and necessitates an additional step.

To further extend the method proposed herein, it would be necessary to interpret the transformations in the molecular structure of the amino acids occurring in each mutation. Similarly to the asymmetry of the amino acid transformations in the step matrix, the sequence of mutations occurring within a codon is not regular. The probability of the first mutation occurring in the first or second nitrogenated base may depend on their molecular structures.

\section{Example of an application of our method}

To illustrate our method, we present in this section a phylogenetic analysis of nine snake taxa belonging to Philodryas and Tropidodryas (Serpentes), included in the monophyletic taxon Philodryadini (Ferrarezzi, 1994). As outgroups we used Xenodon neuwiedi and Oxyrhopus guibei, both belonging to Xenodonthini, which is the sister group of Philodryadini, and Thamnophys errans and Nerodia fasciata, which belong to the tribe Thamnopheini. These outgroups were chosen on the basis of the published phylogeny of Ferrarezzi (1994).

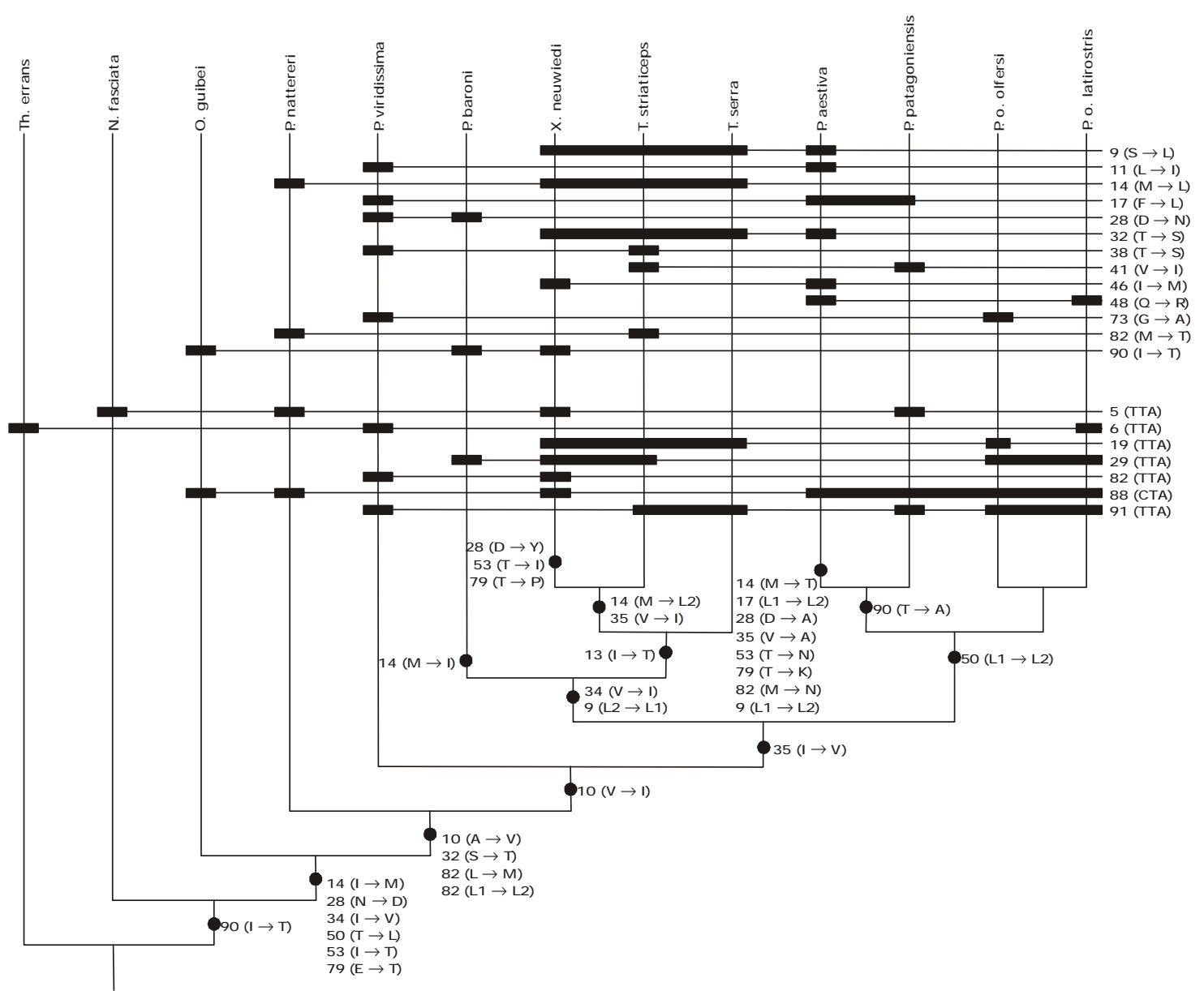

Fig. 2 - Cladogram constructed step by step for complete sequences of amino acids. The numbers on the nodes of the cladogram indicate the positions of amino acids in the DNA sequence, and the letters that follow represent the proposed transformations for each amino acid. Capital letters represent amino acids according to international convention for single letter abbreviations. See legend of Fig. 1 for full names of taxa. 
Sequences of Thamnophys errans and Nerodia fasciata were obtained from GenBank (EMBL) (De Queiroz \& Lawson, 1994). The remaining taxa were sequenced (306 base pairs of cytochrome b) and deposited in the GenBank under the following numbers: AF236804 to AF236814.

The results of the alignments of nucleotides and amino acids appear in Appendices 3 and 4, respectively. Fig. 1a represents the strict consensus of three equally parsimonious trees obtained with PAUP 4.0 for the complete sequences of nucleotides. Fig. $1 \mathrm{~b}$ shows the consensus analysis of the same data, but from which the third position of each codon was not considered.

Table 1 presents the analysis of transformation series of codon sequences that produced amino acids for more than one species and that were used as synapomorphies. Also shown in Table 1 are the transformation series for codons and amino acids, the kind of substitution (transition or transversion), and the total number of steps required for amino acid substitutions. The stepwise analysis presented in Table 1 served to construct the cladogram displayed in Fig. 2.

\section{DISCUSSION}

We are not the first to propose a priori estimations of phylogenetic information conserved in aligned sequences. One indication that the quality of sequence data must be determined a priori is the observation that high bootstrap supports can result from chance similarities or long branch effects (Otto et al., 1996). The belief of many researchers that it is possible to obtain monophyletic groups without establishing $a$ priori hypotheses of character transformation may represent a dream (Wägele, 1994). The a posteriori polarization of characters is based on circular argumentation, since the resulting hypotheses are then used to corroborate the hypothesis obtained in the cladogram (Wägele, 1994). We conclude that perfect methods of analysis do not exist. While some researchers perceive character polarizations as introducing apriorisms into the analysis, according to others avoiding such polarizations produce circular arguments in the analysis.

Progress in the analysis of sequence data would thus seem to depend on the continued search for new methods to estimate the quality of the data used in an analysis. Philippe et al. (1994) concluded that the ssu rDNA molecule does not contain information adequate for several nodes of the tree for the Cambrian radiation of metazoans. Wägele \& Rödding (1998) show that in analyses of published 18S rDNA alignments the signal-to-noise relationship varies greatly in a way not detected by conventional construction methods. Thus, not every seemingly "good" tree actually represents phylogeny. Unrelated species may share by chance alone one of the four possible nucleotides at a site (Maley \& Marshall, 1998). The accumulation of these chance events between distantly related species will tend to overwhelm the similarities present due to the shared ancestry of more closely related taxa (Felsenstein, 1978). When biological knowledge is obtained about what is happening to characters during evolution, our initial biological hypotheses may eventually need to be reinterpreted. Consensus trees will not be sufficient to establish any definitive topology for these characters (Bremer, 1988). Consensus trees are not sufficient to establish phylogeny because of the high saturation level affecting nucleotides. Although amino acid sequences correct for saturation, they have been considered as being subject to convergence and as ignoring phylogenetically informative variation (Simmons, 2000). We do not agree with this position, however. Our method attempts to avoid the high saturation level of nucleotides in synonymous positions (= noise), considering non-synonymous substitutions.

Comparing the consensus tree obtained with PAUP with the asymmetric step matrix (Fig. 1c, d) and with the tree constructed with our method (Fig. 2), a few interesting dedications may be made. One of the two most parsimonious trees found by PAUP is identical to the topology obtained with our method, with the exception of the relative positions of the two outgroups. The conflict occurs mainly due to different interpretations regarding position 57 of the sequence of amino acids. The PAUP program obtains Isoleucine, an autapomorphy for Thamnophys errans, as plesiomorphic. We gave priority to position 90 over 57 , because it represents a synapomorphy that unites Nerodia fasciata to the remaining taxa, excluding T. errans to a more basal position. The interpretation of characters in positions 90,32 , and 28 is responsible for the variation in topology between the two trees found with PAUP (Fig. 1c, d), in which the positions of Philodryas natteri, $P$. viridissina, and P. baroni are interchanged. Although both trees are equally parsimonious when we consider only the number of evolutionary steps, we opt for the tree that coincides with the result of our stepwise analysis (Fig. 1d). 
TABLE 1

Transformation series analysis of amino acid sequences and their codons.

\begin{tabular}{|c|c|c|c|c|c|}
\hline $\begin{array}{l}\text { Seq.p } \\
\text { os. }\end{array}$ & $\begin{array}{l}\text { Sampled amino } \\
\text { acids }\end{array}$ & $\begin{array}{c}\text { Sampled } \\
\text { codons }\end{array}$ & Transformation series (codons) & $\begin{array}{c}\text { Transformation } \\
\text { series (amino } \\
\text { acids) }\end{array}$ & Changes \\
\hline \multirow[t]{2}{*}{9} & & & & & $\begin{array}{l}2 \text { steps, } 2 \\
\text { AA }\end{array}$ \\
\hline & Ser, Leu & $\mathrm{TCPu}, \mathrm{CTA}$ & $(\mathrm{TCG} \rightarrow \mathrm{TCA}) \rightarrow \mathrm{TTA} \rightarrow \mathrm{CTA}$ & $\underset{(\mathrm{Ser} \rightarrow \mathrm{Ser}) \rightarrow \mathrm{Leu}_{1} \rightarrow}{\mathrm{Leu}_{2}} \rightarrow$ & $1 \mathrm{~s}, 2 \mathrm{~s}, 3 \mathrm{~s}$ \\
\hline \multirow[t]{4}{*}{10} & & & & & $\begin{array}{c}7 \text { steps, } 5 \\
\text { AA }\end{array}$ \\
\hline & Ala, Val & $\begin{array}{l}\text { GC(A,C,T), } \\
\text { GTA }\end{array}$ & $\mathrm{GCPi} \rightarrow \mathrm{GCA} \rightarrow \mathrm{GTA}$ & $\underset{\text { Val }}{\left(\begin{array}{c}\text { Ala } \rightarrow \text { Ala } \\
\text { Val }\end{array}\right.} \rightarrow$ & $2 \mathrm{~s}, 3 \mathrm{sv}$ \\
\hline & Val, Ile & GTA, ATPi & $\mathrm{GTA} \rightarrow \mathrm{GTPi} \rightarrow \mathrm{ATPi}$ & $(\mathrm{Val} \rightarrow \mathrm{Val}) \rightarrow \mathrm{Ile}$ & $1 \mathrm{~s}, 3 \mathrm{v}$ \\
\hline & Ile, Tyr & ATC, TAT & $\begin{array}{l}(\mathrm{ATC} \rightarrow \mathrm{ATT}) \rightarrow \mathrm{AAT} \rightarrow \mathrm{TAT} \\
(\mathrm{ATC} \rightarrow \mathrm{ATT}) \rightarrow \mathrm{TTT} \rightarrow \mathrm{TAT}\end{array}$ & $\begin{array}{c}(\mathrm{Ile} \rightarrow \mathrm{Ile}) \rightarrow \\
\text { Asn } \rightarrow \text { Tyr } \\
(\mathrm{Ile} \rightarrow \mathrm{Ile}) \rightarrow \\
\mathrm{Phe} \rightarrow \mathrm{Tyr}\end{array}$ & $\begin{array}{l}1 \mathrm{v}, 2 \mathrm{v}, 3 \mathrm{~s} \\
1 \mathrm{v}, 2 \mathrm{v}, 3 \mathrm{~s}\end{array}$ \\
\hline \multirow[t]{2}{*}{11} & & & & & $\begin{array}{l}2 \text { steps, } 2 \\
\text { AA }\end{array}$ \\
\hline & Leu, Ile & CTA, ATT & $\mathrm{CTA} \rightarrow \mathrm{CTT} \rightarrow \mathrm{ATT}$ & Leu $\rightarrow$ Leu $\rightarrow$ Ile & $1 \mathrm{v}, 3 \mathrm{v}$ \\
\hline \multirow[t]{2}{*}{13} & & & & & $\begin{array}{l}2 \text { steps, } 2 \\
\text { AA }\end{array}$ \\
\hline & Ile, Thr & ATPi, ACC & $\mathrm{ATT} \rightarrow \mathrm{ATC} \rightarrow \mathrm{ACC}$ & $\mathrm{Ile} \rightarrow \mathrm{Ile} \rightarrow \mathrm{Thr}$ & $2 \mathrm{~s}, 3 \mathrm{~s}$ \\
\hline \multirow[t]{4}{*}{14} & & & & & $\begin{array}{l}4 \text { steps, } 4 \\
\text { AA }\end{array}$ \\
\hline & Ile, Met & ATPi, ATA & $\mathrm{ATPi} \Leftrightarrow \mathrm{ATA}$ & Ile $\Leftrightarrow$ Met & $3 v$ \\
\hline & Met, Leu & ATA, CTA & $\mathrm{ATA} \rightarrow(\mathrm{CTA} \Leftrightarrow \mathrm{TTA})$ & 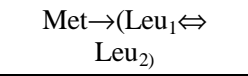 & $1 \mathrm{v}$ \\
\hline & Met, Thr & ATA, ACC & $\mathrm{ATA} \rightarrow \mathrm{ATC} \rightarrow \mathrm{ACC}$ & Met $\rightarrow \mathrm{Ile} \rightarrow \mathrm{Thr}$ & $2 \mathrm{~s}, 3 \mathrm{v}$ \\
\hline \multirow[t]{2}{*}{17} & & & & & 1 step, 2 AA \\
\hline & Ser, Leu & TTN, CTA & $\mathrm{TTN} \rightarrow(\mathrm{TTA} \rightarrow \mathrm{CTA})$ & $\begin{array}{l}\mathrm{Ser} \rightarrow\left(\mathrm{Leu}_{1} \rightarrow\right. \\
\left.\quad \mathrm{Leu}_{2}\right)\end{array}$ & $1 \mathrm{~s}, 3 \mathrm{v}$ \\
\hline \multirow[t]{4}{*}{28} & & & & & $\begin{array}{c}3 \text { steps, } 3 \\
\text { AA }\end{array}$ \\
\hline & Asn, Asp & AAC, GAPi & $\mathrm{AAC} \Leftrightarrow(\mathrm{GAC} \rightarrow \mathrm{GAT})$ & Asn $\Leftrightarrow($ Asp $\rightarrow$ Asp $)$ & $1 \mathrm{~s}, 3 \mathrm{~s}$ \\
\hline & Asp, Tyr & GAC, TAC & $\mathrm{GAC} \rightarrow \mathrm{TAC}$ & Asp $\rightarrow$ Tyr & $1 \mathrm{v}$ \\
\hline & Asp, Ala & GAC, GCC & $\mathrm{GAC} \rightarrow \mathrm{GCC}$ & $\mathrm{Asp} \rightarrow \mathrm{Ala}$ & $2 \mathrm{v}$ \\
\hline \multirow[t]{2}{*}{32} & & & & & 1 step, 2 AA \\
\hline & Ser, Thr & $\mathrm{TC}(\mathrm{A}, \mathrm{C}), \mathrm{ACA}$ & $(\mathrm{TCC} \rightarrow \mathrm{TCA}) \Leftrightarrow \mathrm{TCC}$ & $(\mathrm{Ser} \rightarrow \mathrm{Ser}) \Leftrightarrow \mathrm{Thr}$ & $1 \mathrm{v}, 3 \mathrm{v}$ \\
\hline \multirow[t]{2}{*}{34} & & & & & $\begin{array}{c}2 \text { steps, } 2 \\
\text { AA }\end{array}$ \\
\hline & Ile, Val & $\begin{array}{c}\text { ATPi, } \\
\text { GT(A,C,T) }\end{array}$ & $(\mathrm{ATT} \rightarrow \mathrm{ATC}) \Leftrightarrow(\mathrm{GTC} \rightarrow \mathrm{GT}(\mathrm{A}, \mathrm{T})$ & $\begin{array}{l}(\mathrm{Ile} \rightarrow \mathrm{Ile}) \Leftrightarrow \\
(\mathrm{Val} \rightarrow \mathrm{Val})\end{array}$ & $1 \mathrm{~s}, 3 \mathrm{sv}$ \\
\hline \multirow[t]{3}{*}{35} & & & & & $\begin{array}{l}2 \text { steps, } 3 \\
\text { AA }\end{array}$ \\
\hline & Ile, Val & ATPi, GTPi & $\mathrm{ATPi} \rightarrow \mathrm{GTPi}$ & $\mathrm{Ile} \rightarrow \mathrm{Val}$ & $1 \mathrm{~s}, 3 \mathrm{~s}$ \\
\hline & Val, Ala & GTPi, GCC & $(\mathrm{GTT} \rightarrow \mathrm{GTC}) \rightarrow \mathrm{GCC}$ & $\begin{array}{l}(\mathrm{Val} \rightarrow \mathrm{Val}) \\
\quad \text { Ala }\end{array}$ & $2 \mathrm{~s}, 3 \mathrm{~s}$ \\
\hline
\end{tabular}


TABLE 1 (Continued.)

\begin{tabular}{|c|c|c|c|c|c|}
\hline $\begin{array}{l}\text { Seq. } \\
\text { pos. }\end{array}$ & $\begin{array}{c}\text { Sampled } \\
\text { amino acids }\end{array}$ & $\begin{array}{l}\text { Sampled } \\
\text { codons }\end{array}$ & $\begin{array}{l}\text { Transformation series } \\
\text { (codons) }\end{array}$ & $\begin{array}{c}\text { Transformation } \\
\text { series (amino } \\
\text { acids) }\end{array}$ & Changes \\
\hline \multirow[t]{3}{*}{38} & & & & & $\begin{array}{c}4 \text { steps, } 3 \\
\text { AA }\end{array}$ \\
\hline & Thr, Ser & $\begin{array}{l}\mathrm{AC}(\mathrm{A}, \mathrm{C}) \\
\mathrm{TCA}\end{array}$ & $(\mathrm{ACC} \rightarrow \mathrm{ACA}) \rightarrow \mathrm{TCA}$ & $\begin{array}{l}(\mathrm{Thr} \rightarrow \mathrm{Thr}) \rightarrow \\
\quad \text { Ser }\end{array}$ & $1 \mathrm{v}, 3 \mathrm{v}$ \\
\hline & Thr, Met & $\begin{array}{l}\mathrm{AC}(\mathrm{A}, \mathrm{C}) \\
\text { ATA }\end{array}$ & $(\mathrm{ACC} \rightarrow \mathrm{ACA}) \rightarrow \mathrm{ATA}$ & $\begin{array}{c}(\mathrm{Thr} \rightarrow \mathrm{Thr}) \rightarrow \\
\text { Met }\end{array}$ & $2 \mathrm{~s}, 3 \mathrm{v}$ \\
\hline \multirow[t]{2}{*}{41} & & & & & $\begin{array}{c}1 \text { step, } 2 \\
\text { AA }\end{array}$ \\
\hline & Val, Ile & GTN, ATC & $(\mathrm{GTPu} \rightarrow \mathrm{GTPi}) \rightarrow \mathrm{ATC}$ & $(\mathrm{Val} \rightarrow \mathrm{Val}) \rightarrow \mathrm{Ile}$ & $1 \mathrm{~s}, 3 \mathrm{sv}$ \\
\hline \multirow[t]{2}{*}{46} & & & & & $\begin{array}{c}1 \text { step, } 2 \\
\text { AA }\end{array}$ \\
\hline & Ile, Met & ATPi, ATPu & $\mathrm{ATPi} \rightarrow \mathrm{ATPu}$ & $\mathrm{Ile} \rightarrow \mathrm{Met}$ & $3 \mathrm{sv}$ \\
\hline \multirow[t]{2}{*}{48} & & & & & $\begin{array}{c}1 \text { step, } 2 \\
\text { AA }\end{array}$ \\
\hline & Gln, Arg & CAA, CGA & $\mathrm{CAA} \rightarrow \mathrm{CGA}$ & $\mathrm{Gln} \rightarrow \mathrm{Arg}$ & $2 \mathrm{~s}$ \\
\hline \multirow[t]{3}{*}{$\mathbf{5 0}$} & & & & & $\begin{array}{c}5 \text { steps, } 3 \\
\text { AA }\end{array}$ \\
\hline & Thr, Leu & $\mathrm{ACC}, \mathrm{CTN}$ & $\begin{array}{c}\mathrm{ACC} \rightarrow \mathrm{ATC} \rightarrow(\mathrm{CTC} \rightarrow \mathrm{CTN}) \\
\mathrm{ACC} \rightarrow \mathrm{CCC} \rightarrow \mathrm{CTC} \rightarrow \mathrm{CTN})\end{array}$ & $\begin{array}{c}\mathrm{Thr} \rightarrow \mathrm{Ile} \rightarrow(\mathrm{Leu} \rightarrow \\
\text { Leu }) \\
\mathrm{Thr} \rightarrow \mathrm{Pro} \rightarrow \\
(\mathrm{Leu} \rightarrow \text { Leu })\end{array}$ & $\begin{array}{l}1 \mathrm{v}, 2 \mathrm{~s}, 3 \mathrm{sv} \\
1 \mathrm{v}, 2 \mathrm{~s}, 3 \mathrm{sv}\end{array}$ \\
\hline & Leu & CTN, TTA & $(\mathrm{CTN} \rightarrow \mathrm{CTA}) \rightarrow \mathrm{TTA}$ & $\mathrm{Leu}_{1} \rightarrow \mathrm{Leu}_{2}$ & $1 \mathrm{~s}, 3 \mathrm{sv}$ \\
\hline \multirow[t]{3}{*}{53} & & & & & $\begin{array}{c}3 \text { steps, } 3 \\
\text { AA }\end{array}$ \\
\hline & Ile, $\mathrm{Thr}$ & ATC, ACPi & $\mathrm{ATC} \Leftrightarrow(\mathrm{ACC} \rightarrow \mathrm{ACT})$ & $\mathrm{Ile} \Leftrightarrow(\mathrm{Thr} \rightarrow \mathrm{Thr})$ & $2 \mathrm{~s}, 3 \mathrm{~s}$ \\
\hline & Thr, Asn & $\mathrm{ACC}, \mathrm{AAC}$ & $\mathrm{ACC} \rightarrow \mathrm{AAC}$ & $\mathrm{Thr} \rightarrow$ Asn & $2 \mathrm{v}$ \\
\hline \multirow[t]{2}{*}{73} & & & & & $\begin{array}{c}1 \text { step, } 2 \\
\text { AA }\end{array}$ \\
\hline & Gly, Ala & GGN, GCG & $(\mathrm{GGN} \rightarrow \mathrm{GGG}) \rightarrow \mathrm{GCG}$ & $($ Gly $\rightarrow$ Gly $) \rightarrow$ Ala & $2 \mathrm{v}, 3 \mathrm{sv}$ \\
\hline \multirow[t]{5}{*}{79} & & & & & $\begin{array}{c}5 \text { steps, } 5 \\
\text { AA }\end{array}$ \\
\hline & Glu, Thr & $\mathrm{GAA}, \mathrm{ACPu}$ & $\begin{array}{l}\mathrm{GAA} \rightarrow \mathrm{AAA} \rightarrow(\mathrm{ACA} \rightarrow \mathrm{ACA}) \\
\mathrm{GAA} \rightarrow \mathrm{GCA} \rightarrow(\mathrm{ACA} \rightarrow \mathrm{ACG})\end{array}$ & $\begin{array}{c}\mathrm{Glu} \rightarrow \text { Lys } \rightarrow \\
(\mathrm{Thr} \rightarrow \mathrm{Thr}) \\
\mathrm{Glu} \rightarrow \text { Ala } \rightarrow \\
(\mathrm{Thr} \rightarrow \mathrm{Thr})\end{array}$ & $\begin{array}{l}1 \mathrm{~s}, 2 \mathrm{~s}, 3 \mathrm{~s} \\
1 \mathrm{~s}, 2 \mathrm{~s}, 3 \mathrm{~s}\end{array}$ \\
\hline & Thr, Ala & $\mathrm{ACPu}, \mathrm{GCA}$ & $(\mathrm{ACG} \rightarrow \mathrm{ACA}) \rightarrow \mathrm{GCA}$ & $(\mathrm{Thr} \rightarrow \mathrm{Thr}) \rightarrow$ Ala & $1 \mathrm{~s}, 3 \mathrm{~s}$ \\
\hline & Thr, Lys & $\mathrm{ACPu}, \mathrm{AAG}$ & $(\mathrm{ACA} \rightarrow \mathrm{ACG}) \rightarrow \mathrm{AAG}$ & $(\mathrm{Thr} \rightarrow \mathrm{Thr}) \rightarrow$ Lys & $2 \mathrm{v}, 3 \mathrm{~s}$ \\
\hline & Thr, Pro & $\mathrm{ACPu}, \mathrm{CCA}$ & $(\mathrm{ACG} \rightarrow \mathrm{ACA}) \rightarrow \mathrm{CCA}$ & $(\mathrm{Thr} \rightarrow \mathrm{Thr}) \rightarrow$ Pro & $1 \mathrm{v}, 3 \mathrm{~s}$ \\
\hline
\end{tabular}


TABLE 1 (Continued.)

\begin{tabular}{|c|c|c|c|c|c|}
\hline $\begin{array}{l}\text { Seq. } \\
\text { pos. }\end{array}$ & $\begin{array}{c}\text { Sampled } \\
\text { amino acids }\end{array}$ & $\begin{array}{l}\text { Sampled } \\
\text { codons }\end{array}$ & $\begin{array}{c}\text { Transformation series } \\
\text { (codons) }\end{array}$ & $\begin{array}{l}\text { Transformation } \\
\text { series (amino } \\
\text { acids) }\end{array}$ & Changes \\
\hline \multirow[t]{3}{*}{82} & & & & & $\begin{array}{c}4 \text { steps, } 4 \\
\text { AA }\end{array}$ \\
\hline & Leu, Met & $\begin{array}{c}\text { CTPu, TTA, } \\
\text { ATA }\end{array}$ & $(\mathrm{CTPu} \rightarrow \mathrm{TTA}) \rightarrow \mathrm{ATA}$ & $\begin{array}{c}\left(\mathrm{Leu}_{1} \rightarrow \mathrm{Leu}_{2}\right) \rightarrow \\
\mathrm{Met}\end{array}$ & $1 \mathrm{v}, 3 \mathrm{~s}$ \\
\hline & Met, Thr & ATA, ACA & $\mathrm{ATA} \rightarrow \mathrm{ACA}$ & Met $\rightarrow$ Thr & $2 \mathrm{~s}$ \\
\hline \multirow[t]{4}{*}{90} & & & & & $\begin{array}{c}4 \text { steps, } 3 \\
\text { AA }\end{array}$ \\
\hline & Ile, Thr & $\begin{array}{l}\mathrm{AT}(\mathrm{C}, \mathrm{T}) \\
\mathrm{ACC}\end{array}$ & $\mathrm{AT}(\mathrm{C}, \mathrm{T}) \rightarrow \mathrm{ACC}$ & $\mathrm{Ile} \rightarrow \mathrm{Thr}$ & $2 \mathrm{~s}$ \\
\hline & Thr, Ala & $\begin{array}{c}\mathrm{ACC} \\
\mathrm{GC}(\mathrm{A}, \mathrm{C})\end{array}$ & $\mathrm{ACC} \rightarrow(\mathrm{GCC} \rightarrow \mathrm{GCA})$ & $\mathrm{Thr} \rightarrow(\mathrm{Ala} \rightarrow \mathrm{Ala})$ & $1 \mathrm{~s}, 3 \mathrm{v}$ \\
\hline & Thr, Ile & ACC, ATT & $\mathrm{ACC} \rightarrow(\mathrm{ACT} \rightarrow \mathrm{ATT})$ & $\mathrm{Thr} \rightarrow(\mathrm{Thr} \rightarrow \mathrm{Ile})$ & $2 \mathrm{~s}, 3 \mathrm{~s}$ \\
\hline
\end{tabular}

Note. Sequence position (seq. pos.), Purine (Pu), Pyrimidine (Pi), direction of transformation series $(\rightarrow)$, reversion $(\Leftrightarrow)$, nitrogenated base position in codon $(1,2,3)$, amino acid (AA), transition (s), both transition and transversion (sv), transversion (v).

This tree has 13 steps (12 altering amino acids, and only one altering a codon of Leucine), while the alternative tree proposed by PAUP has only 12 steps (10 altering amino acids, and two altering codons of Leucine). We consider that nonsynonymous amino acid substitutions are biologically more informative than synonomous amino acid substitutions.

The above example leads us to consider several ways in which to reduce the large amount of noise that tends to confound molecular analyses. Ambiguous alignments may be excluded from the data matrix, different weights may be attributed to characters with distinct complexities, transitions or transversions may be excluded from consideration, or third codon positions may be ignored (Gatesy et al., 1993; Simmons et al., 1994; Wägele \& Rödding, 1998). If there are no transversions in an analysis, there will occur no signal. On the other hand, transition substitutions will decrease the phylogenetic signal (Swofford et al., 1996a).

Of the 306 base pairs present in the studied gene, only 19 codons were considered informative in a phylogenetic context (autapomorphies excluded) (Table 1). Our method separates noise from signal in a phylogenetic analysis of sequence data, by hypothesizing explicit transformation series for each informative codon. In this sense, our sequence analysis is very similar to qualitative cladistic analyses of morphological characters, in which only those characters that can be successfully interpreted in a phylogenetic context are introduced into the analysis.

Analysis of homology of sequence data is thus seen to have the same logical basis as in studies of comparative morphology. To identify phylogenetic signal beyond the threshold defined by chance similarities it is necessary to consider the information content of characters. Thus, even though positions of nucleotides within a sequence are not complex and have low information content (Wägele \& Wetzel, 1994), they can still be profitably included in a qualitative cladistic analysis when the evaluation of their phylogenetic information content is attempted. 
APPENDIX 1

Asymmetric step matrix for non-synonymous nucleotide substitutions based on vertebrate mitochondrial genetic code.

\begin{tabular}{|c|c|c|c|c|c|c|c|c|c|c|c|c|c|c|c|c|c|c|c|c|c|c|c|c|c|c|c|c|c|c|c|}
\hline & \multirow{3}{*}{\begin{tabular}{|c|c}
$\begin{array}{c}\text { Amino } \\
\text { acid }\end{array}$ \\
Codon \\
Symbol
\end{tabular}} & \multicolumn{2}{|c|}{\begin{tabular}{|l|l|} 
PHE & LEU \\
\end{tabular}} & \multicolumn{2}{|c|}{ LEU } & & \multicolumn{3}{|c|}{\begin{tabular}{|l|l|} 
MET & VAL \\
\end{tabular}} & & & & & \multicolumn{3}{|c|}{\begin{tabular}{|l|l|l|} 
TYR & HIS & GLN \\
\end{tabular}} & \multicolumn{2}{|c|}{\begin{tabular}{|l|l|} 
ASN & LYS \\
\end{tabular}} & \multicolumn{2}{|c|}{\begin{tabular}{|l|l|} 
ASP & GLU \\
\end{tabular}} & \multicolumn{2}{|c|}{\begin{tabular}{|l|l|} 
CYS & TRP \\
\end{tabular}} & & & \multicolumn{2}{|c|}{ GLY } \\
\hline & & UUY & UUR & CUY & CUR & AUY & AUR & GUY & GUR & UCY & UCR & $\mathrm{CCY}$ & $\mathrm{CCR}$ & $\mathbf{A C Y}$ & ACR & $\mathrm{GCY}$ & GCI & UAY & CAY & Cav & AAY & AAR & GAY & GAR & UGY & UGR & CGY & CGR & AGY & GGY & GGR \\
\hline & & $\mathbf{A}$ & B & C & D & $\mathbf{E}$ & $\mathbf{F}$ & G & H & I & $\mathbf{J}$ & $\mathbf{K}$ & $\mathbf{L}$ & M & $\mathbf{N}$ & 0 & $\mathbf{P}$ & Q & $\mathbf{R}$ & $\mathbf{S}$ & $T$ & $\mathbf{U}$ & $\mathrm{V}$ & W & $\mathbf{X}$ & $\mathbf{Y}$ & $\mathbf{Z}$ & 1 & 2 & 3 & 4 \\
\hline \begin{tabular}{|l|} 
Amino acid \\
\end{tabular} & Codon & & & & & & & & & & & & & & & & & & & & & & & & & & & & & & \\
\hline PHE & UUY & 0 & 1 & 1 & 1 & 1 & 2 & 1 & 1 & 1 & 1 & 2 & 2 & 2 & 2 & 2 & 2 & 1 & 2 & 3 & 2 & 3 & 2 & 3 & 1 & 2 & 2 & 2 & 2 & 2 & 2 \\
\hline LEU & UUR & 1 & $\mathbf{0}$ & 1 & 1 & 2 & 1 & 1 & 1 & 1 & 1 & 2 & 22 & 2 & 2 & 2 & 2 & 2 & 3 & 2 & 3 & 2 & 3 & 2 & 2 & 1 & 2 & 2 & 2 & 2 & 2 \\
\hline FU & CUY & 1 & 2 & 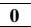 & $\mathbf{0}$ & 1 & 2 & 1 & 1 & 2 & 2 & 1 & 1 & 2 & 2 & 2 & 2 & 2 & 1 & 2 & 2 & 3 & 2 & 3 & 2 & 3 & 4 & 1 & 2 & 2 & 2 \\
\hline LEU & CUR & 2 & 1 & 0 & 0 & 2 & 1 & 1 & 1 & 2 & 2 & 1 & 1 & 2 & 2 & & 2 & 3 & 2 & 1 & 3 & 2 & 3 & 2 & 3 & 2 & 4 & 1 & 3 & 2 & 2 \\
\hline ILE & AUY & 1 & 2 & 1 & 1 & $\mathbf{0}$ & 1 & 1 & 1 & 2 & 2 & 2 & 2 & 1 & 1 & 2 & 2 & 2 & 2 & 3 & 1 & 2 & 2 & 3 & 2 & 3 & 2 & 2 & 1 & 2 & 2 \\
\hline MET & AUR & 2 & 1 & 1 & 1 & 2 & 0 & 2 & 2 & 2 & 2 & 2 & 2 & 1 & 1 & & 2 & 3 & 3 & 2 & 2 & 1 & 3 & 2 & 3 & 2 & 2 & 2 & 2 & 2 & 2 \\
\hline VI & GUY & 1 & 22 & 1 & 1 & 1 & 2 & 0 & 0 & 2 & 2 & 2 & 2 & 2 & 2 & 1 & 1 & 2 & 2 & 3 & 2 & 3 & 1 & 2 & 2 & 3 & 2 & 2 & 2 & 1 & 1 \\
\hline VLA & GUR & 2 & 1 & 1 & 1 & 2 & 1 & 0 & 0 & 2 & 2 & 2 & 2 & 2 & 2 & 1 & 1 & 3 & 3 & 2 & 3 & 2 & 2 & 2 & 3 & 2 & 2 & 2 & 3 & 1 & 1 \\
\hline SER & UCY & 1 & 2 & 2 & 2 & 2 & 3 & 2 & 2 & 0 & 0 & 1 & 1 & 1 & 1 & 1 & 1 & 1 & 2 & 3 & 2 & 3 & 2 & 3 & 1 & 2 & 2 & 2 & 2 & 2 & 2 \\
\hline SEK & UCR & 2 & 1 & 2 & 2 & 3 & 2 & 2 & 2 & 0 & 0 & 1 & 1 & 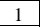 & 1 & 1 & 1 & 2 & 3 & 2 & 3 & 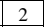 & 3 & 2 & 2 & 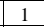 & 2 & 2 & 3 & 2 & 2 \\
\hline PRO & $\mathrm{CCY}$ & 2 & 3 & 1 & 1 & 2 & 3 & 2 & 2 & 1 & 1 & 0 & 0 & 1 & 1 & 1 & 1 & 2 & 1 & 2 & 2 & 3 & 2 & 3 & 2 & 3 & 1 & 1 & 2 & 2 & 2 \\
\hline PरO & $\mathrm{CO}$ & 3 & 2 & 1 & 1 & 3 & 2 & 2 & 2 & 1 & 1 & 0 & 0 & 1 & 1 & 1 & 1 & 3 & 2 & 1 & 3 & 2 & 8 & 2 & 3 & 2 & 1 & 1 & 3 & 2 & 2 \\
\hline THR & $\mathrm{ACY}$ & 2 & 3 & 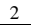 & 2 & 1 & 2 & 2 & 2 & 1 & 1 & 1 & 1 & 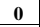 & 0 & & 1 & 2 & 2 & 3 & 1 & 2 & 2 & 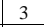 & 2 & 3 & 2 & 2 & 1 & 2 & 2 \\
\hline 1 III & ACR & 3 & 2 & 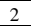 & 2 & 2 & 1 & 2 & 2 & 1 & 1 & 1 & 1 & 0 & 0 & & 1 & 3 & 3 & 2 & 2 & 1 & 3 & 2 & 3 & 2 & 2 & 2 & 2 & 2 & 2 \\
\hline A & GCY & 2 & 3 & 2 & 2 & 2 & 3 & 2 & 2 & 1 & 1 & 1 & 1 & 1 & 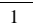 & 0 & 0 & 2 & 2 & 3 & 2 & 3 & 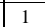 & 2 & 2 & 3 & 2 & 2 & 2 & 1 & 1 \\
\hline ALA & GCR & 3 & 2 & 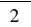 & 2 & 3 & 2 & 1 & 1 & 1 & 1 & 1 & 1 & 1 & 1 & 0 & 0 & 3 & 3 & 2 & 3 & 2 & 2 & 1 & 3 & 2 & 2 & 2 & 3 & 1 & 1 \\
\hline TYR & UAY & 1 & 2 & 2 & 2 & 2 & 3 & 2 & 2 & 1 & 1 & 2 & 2 & 2 & 2 & 2 & 2 & 0 & 1 & 2 & 1 & 2 & 1 & 2 & 1 & 2 & 2 & 2 & 2 & 2 & 2 \\
\hline HIS & CAY & 2 & 3 & 1 & 1 & 2 & 3 & 2 & 2 & 2 & 2 & 1 & 1 & 2 & 2 & 2 & \begin{tabular}{|l|}
2 \\
\end{tabular} & 1 & 0 & 1 & 1 & 2 & 1 & 2 & 2 & 3 & 1 & 1 & 2 & 2 & 2 \\
\hline GLN & CAR & 3 & 2 & 1 & 1 & 3 & 2 & 2 & 2 & 2 & 2 & 1 & 1 & 2 & 2 & 2 & 2 & 2 & 1 & 0 & 2 & 1 & 2 & 1 & 3 & 2 & 1 & 1 & 3 & 2 & 2 \\
\hline ASN & A & 2 & 3 & 2 & 2 & 1 & 2 & 2 & 2 & 2 & 2 & 2 & 2 & 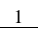 & 1 & 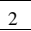 & 2 & 1 & 1 & 2 & 0 & 1 & 1 & 2 & 2 & 3 & 2 & 2 & 1 & 2 & 2 \\
\hline LYS & A & 3 & 2 & 2 & 2 & 2 & 1 & 2 & 2 & 2 & 2 & 2 & 2 & 1 & 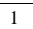 & 2 & 2 & 2 & 2 & 1 & 1 & 0 & 2 & 1 & 3 & 2 & 2 & 2 & 2 & 2 & 2 \\
\hline ASP & GAY & 2 & 3 & 2 & 2 & 2 & 3 & 1 & 1 & 2 & 2 & 2 & 2 & 2 & 2 & 1 & 1 & 1 & 1 & 2 & 1 & 2 & 0 & 1 & 2 & 3 & 2 & 3 & 2 & 1 & 1 \\
\hline GLU & GAR & 3 & 22 & 2 & 2 & 3 & 2 & 1 & 1 & 2 & 2 & 22 & 2 & 2 & 2 & 1 & 1 & 2 & 2 & 1 & 2 & 1 & 1 & 0 & 3 & 2 & 2 & 2 & 3 & 2 & 2 \\
\hline CYS & UGY & 1 & 2 & 2 & 2 & 2 & 3 & 2 & 2 & 1 & 1 & 2 & 2 & 2 & 2 & 2 & 2 & 1 & 2 & 3 & 2 & 3 & 2 & 3 & 0 & 1 & 1 & 1 & 1 & 1 & 1 \\
\hline TRP & UGR & 2 & 1 & 2 & 2 & 3 & 2 & 2 & 2 & 1 & 1 & 22 & 22 & 2 & 2 & 2 & 2 & 2 & 3 & 2 & 3 & 2 & 3 & 2 & 1 & 0 & 1 & 1 & 2 & 1 & 1 \\
\hline$A \mathrm{PC}$ & CGY & 2 & 3 & 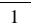 & 1 & 2 & 3 & 2 & 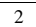 & 2 & 2 & 1 & 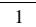 & 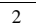 & 2 & 2 & 2 & 2 & 1 & 2 & 2 & 3 & 2 & 3 & 1 & 2 & 0 & 0 & & 1 & 1 \\
\hline AKU & CGR & 3 & 2 & 1 & 1 & 3 & 2 & 2 & 2 & 2 & 2 & 1 & 1 & 2 & 2 & 2 & 2 & 3 & 2 & 1 & 3 & 2 & 5 & 2 & 2 & 1 & 0 & 0 & 2 & 1 & 1 \\
\hline SER & AGY & 2 & 3 & 2 & 2 & 1 & 2 & 2 & 2 & 2 & 2 & 2 & 2 & 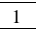 & 1 & 2 & 2 & 2 & 2 & 3 & 1 & 2 & 2 & 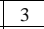 & 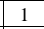 & 2 & 1 & 1 & 0 & 1 & 1 \\
\hline & GG & 2 & 3 & 2 & 2 & 2 & 3 & 1 & 1 & 2 & 2 & 2 & 2 & 2 & 2 & 1 & 1 & 2 & 2 & 3 & 2 & 3 & 1 & 3 & 1 & 2 & 1 & 1 & 1 & 0 & 0 \\
\hline & GGR & 3 & 2 & 2 & 2 & 3 & 2 & 1 & 1 & 22 & 2 & 22 & 2 & 2 & 2 & 1 & \begin{tabular}{|l|}
1 \\
\end{tabular} & 3 & 3 & 2 & 3 & 2 & 2 & 2 & 2 & 1 & 1 & 1 & 2 & 0 & 0 \\
\hline
\end{tabular}

\section{Matrix for studied species according to the adopted coding from the asymmetric step matrix (Appendix 1). See} legend of Fig. 1 for full names of taxa.

\footnotetext{
P. o. latirostris

P. o. olfersi

P. nattereri

P. viridissima

P. patagoniensis

P. aestiva

T. serra

T. striaticeps

o. guibei

$X$. neuwiedi

$P$. baroni

N. fasciata

Th. errans
}

P. o. latirostris

P. o. olfersi

P. nattereri

P. viridissima

$P$. patagoniensis

P. aestiva

T. serra

T. striaticeps

O. guibei

$X$. neuwiedi

$P$. baroni

N. fasciata

Th. errans
3 IFDBMX JED SEFM3AADP ERQNOTEVBOAN I GGREJ1VGLQ3YEF1TBR A3 IFDDMX JED SEFM3AABPERQNOTEVBOAN I GGREJ1VGLQ3YEFSTBR A3 IFBDMX JHD SEDM3AADP ERQNOTEVDOAN I GEREN1VGLQ3YEF STCR A3 IFDBMXJQESEFM3BADPERQNOTETDP ANI HEREJ1VGLQ3YEFSTCR A3 JFBDMXJEDSEFM3BADPERQNOTEVDOAN I HGREN1VELQ3YEFSTBR A3 JCD 3MXDEESEMN3DADPFRQNLVNOJOA I JGOREM1VGTQ3YFE1QBR A3 IFDDMXBED SMDM4 AABPERQNOTEVDOAJIEGREN1VGLQ3YEF STCR A 3 IFDDMXBED SMBM3AABP ERQNOTEVBOAJIEEREJ1VEKQ3YEFSTDR A3 IFCD IXJOD SEFN 4 AADOERQNOTEVDOAJ I HEREFZVGLX3YEBSTDR A3 JFBDMXBED SMBN3AABPERQNOTEQBOAJIEEREN1VGKDYYFFSTCR A3 IFDDMX JEDSEEM3AADPERQNOTETBOAN IEGREN1VGLQ3YEFSTCR A 4 IFBDMXJPDS ? EN4AADPERQNOTETDOAJIEEREMZVHLQ4YEF STMR A 4 IFDBMXJOD SEEN4AADPERQNOTETDOAJ IEERENZVHKQ 4 YEF STMR

PM3P IFAAEXEQEREP Z $4 D Q Q 3$ IQDTUNGYF I 4 MMCDEMBFPNOAA 4 QGDL PM3P IFAAEXEQEREP K 4DQQOIQDTUNGYF I 4MMCDEMBFPNOAA 4 QGDL PM3P IF AAEXEQEREP Z 4 CQQ3 I QDTUP HYN I 4 NMCDEMDFPNOAA 4 QGDL PM3P IFAAEXEQEREP Z 4 CQQOIQCTUN3YBJ 4MMDBEMBF PNOAA 4QGDL PM3P IFAAEXEQEREP Z 4 CQQ 4 I QDTUNGYF I 4 NMCDEOBFPNOAA 4 QGDK OT3P IFAAEXDACRE $313 B Q Q 4$ JACADUMYTE 3NEDDCPMFONP AF 3QHDL PM3P IFAAEXEQEREP Z 4 CQQ3 IQDTUNHYF I 3OMCBEMBFPMOAA3QGDL PM3P IF AAEXEQEREP Z 4 CQQ3 IQDTUNHYN I 4MMCBGMBFPMOAA3QGDL PM3P IOAAEXEQMREP Z 4 CQQ 4 I QDTUNGYD J 4 MMCDEECFPNOAA 4 QGCL PE 4 OJFAAEXEQEREO? 3CEQ3 ?QDTULGYBJ3E2DDEECFOMOAA 4 QECL PM3P IFAAEXEQEREP ZYCQQ3 I QDTUNGYF I 4M? CBEEDF PNOAA 4 QODL PE3P IEAAEXEQEREP $14 \mathrm{CQQ} 3$ IQCTUWHYD I 4 MMCBEMDFONOAA3QG?? PE3P IFAAEXEQEREP 14 CQQ3 I QDTUWHYD I 4MMCBEEDFONOAA3QGCL 


\title{
APPENDIX 3
}

Aligned sequences of nucleotides from cytochrome $b$ for the studied species of snakes. See legend of Fig. 1 for full names of taxa.

$P$ o. latirostris

$P$ o. olfersi

$P$. nattereri

P. viridissima

$P$. patagoniensis

$P$ aestiva

T serra

T. striaticeps

O. guibei

$X$. neuwiedi

$P$. baroni

N. fasciata

Th. errans

$P$ o. latirostris

$P$ o. olfersi

$P$. nattereri

$P$. viridissima

$P$. patagoniensis

$P$ aestiva

$T$ serra

T. striaticeps

O. guibei

$X$. neuwiedi

$P$. baroni

N. fasciata

Th. errans

$P$ o. latirostris

$P$ o. olfersi

$P$. nattereri

$P$. viridissima

$P$. patagoniensis

$P$ aestiva

$T$ serra

T. striaticeps

O. guibei

$X$. neuwiedi

$P$. baroni

N. fasciata

Th. errans

1 2

\author{
34
}

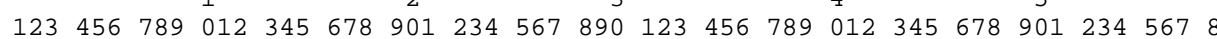
TTT GGC TCC ATA CTA TTA ACC TGC TCA ATC CTA CAA ATC ATA ACC GGC TTC TTC CTA G $\begin{array}{llllllllllllllllllllll}\ldots & \ldots & \ldots & \ldots & \ldots & \ldots & \ldots & \ldots & \ldots & \ldots & \ldots & \ldots & \ldots & \ldots & \ldots & \ldots & \ldots & \ldots & \ldots\end{array}$

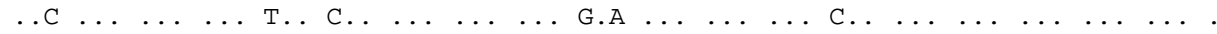
$\begin{array}{lllllllllllllllllllll}\ldots & \ldots & \ldots & \ldots & \ldots & \ldots & \ldots & \ldots & \ldots & \text { ТАТ А.Т } & \ldots & \ldots & \ldots & \ldots & \ldots & \ldots \text { А } & \ldots & \ldots\end{array}$ $\ldots \ldots \ldots$ Т $\ldots$ Т.

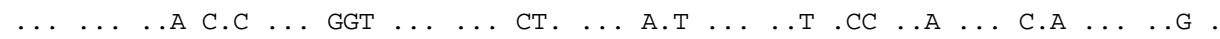

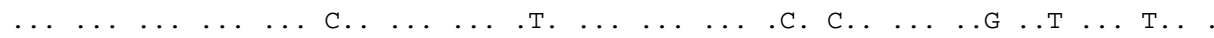

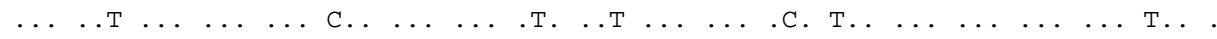

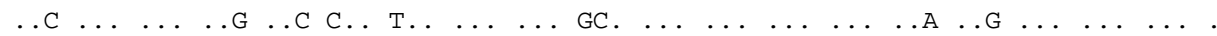

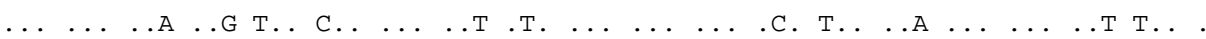
$\begin{array}{llllllllllllllllllllllll}\ldots & \ldots & \ldots & \ldots & \ldots & C & \ldots & \ldots & \ldots G & \ldots & \ldots & \ldots & \ldots & \ldots & \ldots & \ldots & \ldots & \ldots & \ldots G\end{array}$

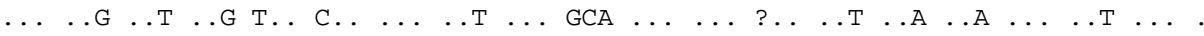

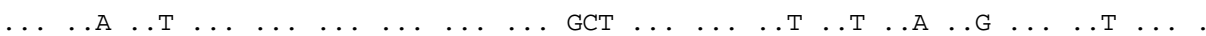

$\begin{array}{llllll}7 & 8 & 9 & 9 & 1 & 111 \\ 8 & 8 & 0 & 001\end{array}$

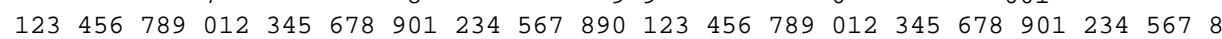
ATC CAC TAC ACA GCT AAT ATC GAC TTA GCT TTC ACA TCC GTT GTC CAC ATC TCA CGA G

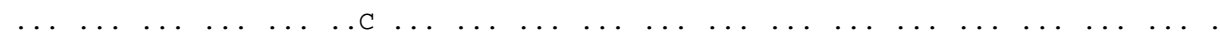

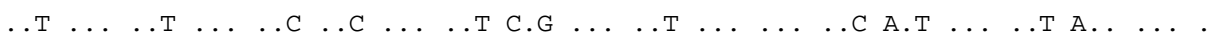

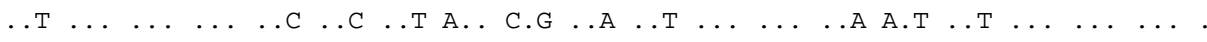

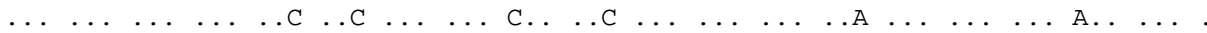

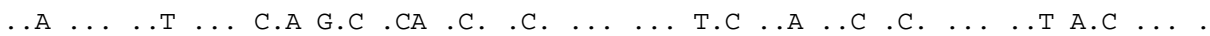

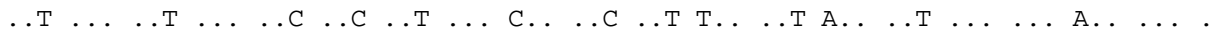

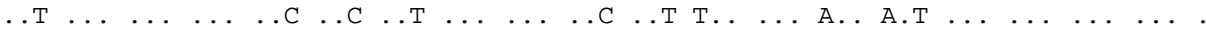

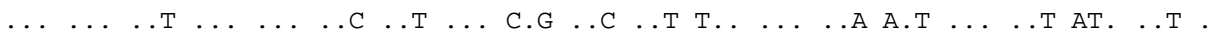

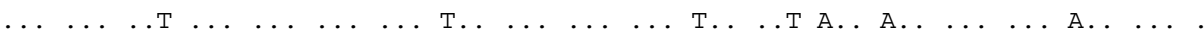

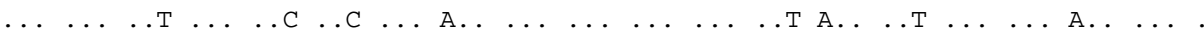

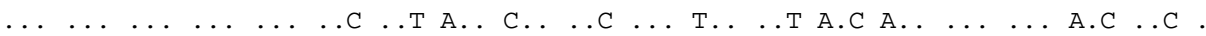

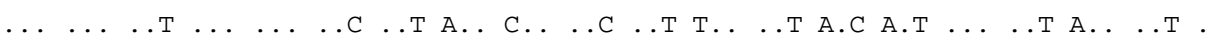

\begin{tabular}{|c|c|c|c|c|c|c|c|c|c|c|c|c|c|c|c|c|c|c|}
\hline & & & 1 & & & 1 & & & 1 & & & & 1 & & & 1 & & \\
\hline 2 & & & 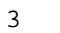 & & & 4 & & & 5 & & & & 6 & & & 7 & & \\
\hline 23 & 456 & 789 & 012 & 345 & 678 & 901 & 234 & 567 & 890 & 123 & 456 & 789 & 012 & 345 & 678 & 901 & 234 & 567 \\
\hline$\Gamma \mathrm{T}$ & $\mathrm{CCA}$ & TAC & GGC & TGA & ATC & ATA & CGA & AAT & TTA & CAT & GCG & ACC & GGC & GCA & TCC & ATA & TTT & TTT \\
\hline . & $\cdots$ & $\cdots$ & $\cdots$ & $\cdots$ & $\cdots$ & $\cdots$ & . A. & $\ldots$ & $\cdots$ & $\ldots$ & $\ldots A$ & $\cdots$ & $\cdots$ & $\cdots$ & $\cdots$ & $\cdots$ & $\cdots$ & $\cdots$ \\
\hline . C & $\ldots$ & $\ldots$ & $\ldots$ & $\ldots$ & $\ldots \mathrm{T}$ & 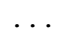 & . A. & $\ldots$ & C.T & $\ldots$ & $\ldots A$ & $\ldots$ & $\ldots$ & $\ldots$ & $\ldots$ & $\ldots$ & $\ldots \mathrm{C}$ & $\ldots C$ \\
\hline . $\mathrm{C}$ & $\ldots$ & $\ldots$ & $\ldots$ & $\ldots$ & $\ldots$ & $\ldots$ & . A. & $\ldots$ & C.T & $\ldots$ & $\ldots A$ & $\ldots$ & $\ldots$ & $\ldots$ & $\ldots \mathrm{T}$ & $\ldots$ & $\ldots C$ & $\ldots C$ \\
\hline . C & $\ldots$ & $\ldots$ & $\ldots$ & $\ldots$ & $\ldots$ & $\ldots$ & . A. & $\ldots$ & $\ldots$ & $\ldots$ & $\ldots A$ & $\ldots$ & $\ldots$ & $\ldots$ & $\ldots \mathrm{T}$ & $\ldots G$ & $\ldots C$ & $\ldots$ \\
\hline$\cdot$ & $A A C$ & $\ldots$ & $\ldots$ & $\ldots$ & $\ldots G$ & $\ldots C$ & $\ldots$ & T.C & $\ldots$ & $\ldots$ & $\ldots \mathrm{T}$ & . A. & . & $\ldots$ & $\ldots$ & $\ldots$ & $\ldots C$ & \\
\hline . C & $\cdots$ & $\ldots$ & $\cdots$ & $\cdots$ & $\cdots$ & $\cdots$ & . A. & $\ldots C$ & C.T & $\cdots$ & $\ldots \mathrm{A}$ & $\cdots$ & $\cdots$ & $\cdots$ & $\ldots \mathrm{T}$ & $\ldots G$ & $\cdots$ & 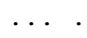 \\
\hline . C & $\ldots \mathrm{T}$ & $\ldots$ & $\ldots$ & $\ldots$ & $\ldots \mathrm{T}$ & $\ldots$ & . A. & $\ldots C$ & C.. & $\ldots$ & $\ldots A$ & $\ldots \mathrm{T}$ & $\ldots$ & $\ldots$ & $\ldots T$ & $\ldots$ & $\ldots$ & $\ldots$ \\
\hline . C & $\ldots G$ &. $\mathrm{G}$. & $\ldots \mathrm{T}$ & $\ldots$ & $\ldots \mathrm{T}$ & T.. & . A. & $\ldots C$ & C.G & $\ldots C$ & $\ldots A$ & $\ldots$ & $\ldots \mathrm{T}$ & $\ldots$ & $\ldots$ & GCC & $\ldots \mathrm{C}$ & $\ldots C$ \\
\hline . C & $\ldots C$ & CTA & T.G & $\ldots$ & $\ldots A$ & $\ldots$ & . A. & $\ldots C$ & C.C & $\ldots$ & $\ldots A$ & . T. & $\ldots A$ & $\ldots C$ & $\ldots A$ & $\ldots$ & $\cdots$ & $\cdots$ \\
\hline - & $\cdots$ & $\cdots$ & $\cdots$ & 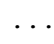 & $\ldots \mathrm{T}$ & $\cdots$ & . A. & $\ldots C$ & C.T & $\cdots$ & $\ldots \mathrm{A}$ & $\cdots$ & $\cdots$ & $\ldots$ & $\ldots T$ & $\ldots$ & $\ldots \mathrm{C}$ & \\
\hline . G & . & $\ldots \mathrm{T}$ & $\ldots \mathrm{A}$ & . & $\ldots T$ & $\cdots$ & . A. & $\ldots C$ & ACC & $\ldots$ & $\ldots A$ & . T. & $\ldots$ & $\ldots$ & $\ldots \mathrm{T}$ & $\ldots \mathrm{T}$ & $\ldots$ & \\
\hline A & . C & $\ldots \mathrm{T}$ & $\ldots G$ & $\ldots$ & $\ldots \mathrm{T}$ & $\ldots$ & . A. & $\ldots C$ & ACC & . & $\ldots A$ & . T. & $\ldots T$ & $\ldots$ & $\ldots$ & 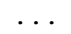 & & \\
\hline
\end{tabular}




\section{APPENDIX 3 (Continued.)}

$P$ o. latirostris

$P$ o. olfersi

P. nattereri

P. viridissima

$P$. patagoniensis

$P$ aestiva

T serra

T. striaticeps

O. guibei

$X$. neuwiedi

P. baroni

$N$. fasciata

Th. errans

$P$ o. latirostris

$P$ o. olfersi

P. nattereri

$P$. viridissima

$P$. patagoniensis

$P$ aestiva

T serra

T. striaticeps

O. guibei

$X$. neuwiedi

P. baroni

N. fasciata

Th. errans

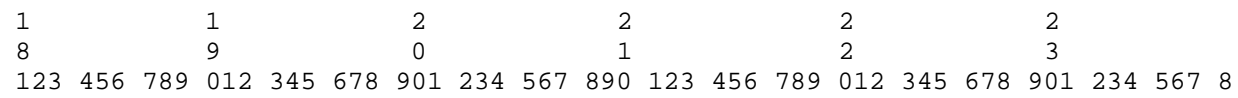
TGC ATC TAC ATC CAC ATC GCA CGC GGA CTA TAC TAC GGC TCC TAC CTA AAC AAA ACA G

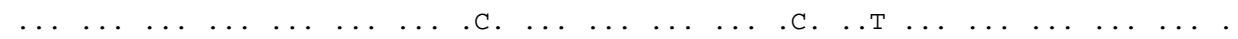

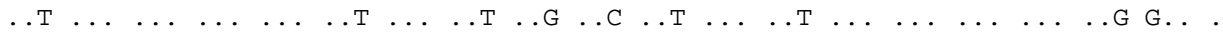

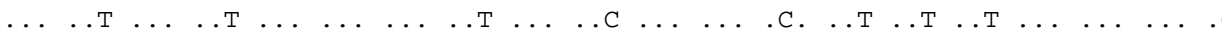
$\begin{array}{llllllllllllllllllllll}\ldots & \ldots & \ldots & \ldots & \ldots & \ldots & \ldots & \ldots & \ldots & \ldots & \ldots & \ldots & \ldots & \ldots \mathrm{T} & \ldots & \ldots & \ldots & \ldots & \ldots \mathrm{G} & .\end{array}$ .. С.А. . Тт С.

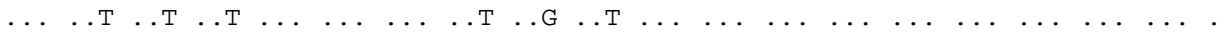

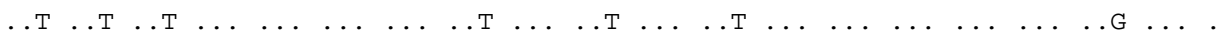

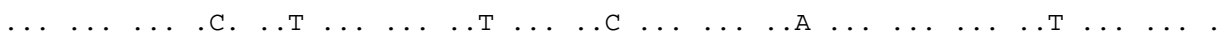

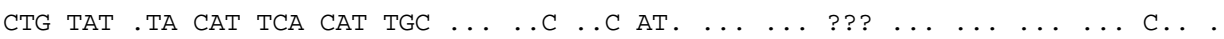
$\begin{array}{llllllllllllllllllllllllll}\ldots & \ldots & \ldots & \ldots & \ldots & \ldots & \ldots & \ldots & \ldots\end{array}$

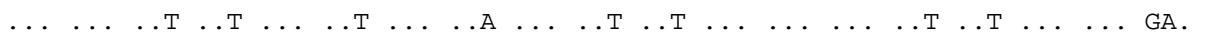

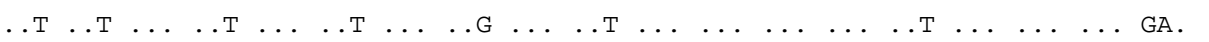

$\begin{array}{llllll}2 & 2 & 2 & 2 & 2 \\ 5 & 6 & 7 & 8 & 9\end{array}$

$\begin{array}{llllllllllllllllllll}123 & 456 & 789 & 012 & 345 & 678 & 901 & 234 & 567 & 890 & 123 & 456 & 789 & 012 & 345 & 678 & 901 & 234 & 567 & 8\end{array}$ TGA ATA TCT GGA ACT ACC CTC CTA ATT ACC TTA ATG GCA ACA GCC TTC TTC GGA TAC GI

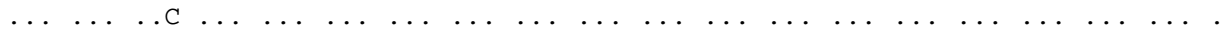

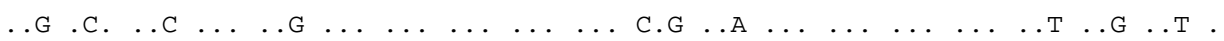

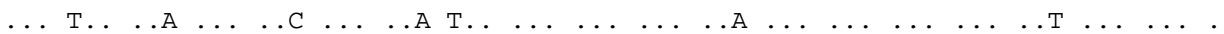
$\begin{array}{lllllllllllllllllllllll}\ldots & \ldots & \ldots & \ldots & \ldots & \ldots & \ldots & \ldots & \ldots & & \ldots\end{array} \ldots$

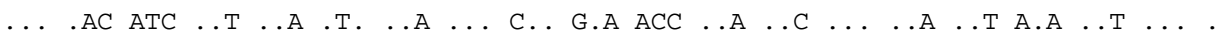

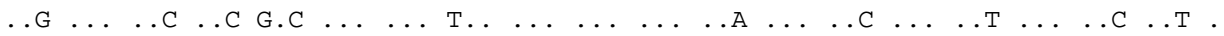

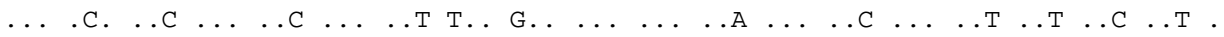

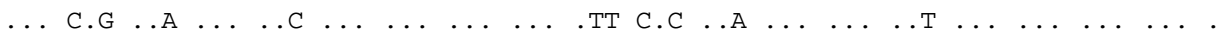

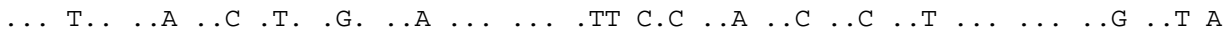

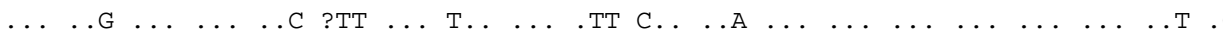

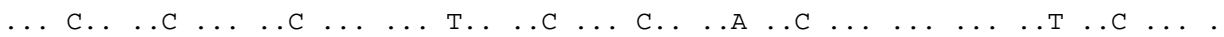

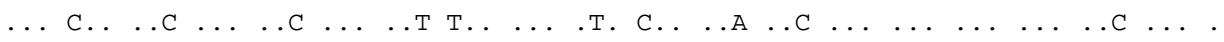

\begin{tabular}{|c|c|}
\hline & 123 \\
\hline$P$ o. latirostris & CTA CC \\
\hline$P$ o. olfersi & .. \\
\hline P. nattereri & $\ldots$ \\
\hline P. viridissima & $\ldots$ \\
\hline P. patagoniensis & $\ldots G$ \\
\hline$P$ aestiva & $\ldots$ \\
\hline$T$ serra & $\cdots$ \\
\hline T. striaticeps & $\ldots$ \\
\hline O. guibei & $\ldots \mathrm{T}$ \\
\hline$X$. neuwiedi & $\ldots \mathrm{T}$. \\
\hline P. baroni & $\ldots$ \\
\hline N. fasciata & .?? \\
\hline Th. errans & . . C \\
\hline
\end{tabular}




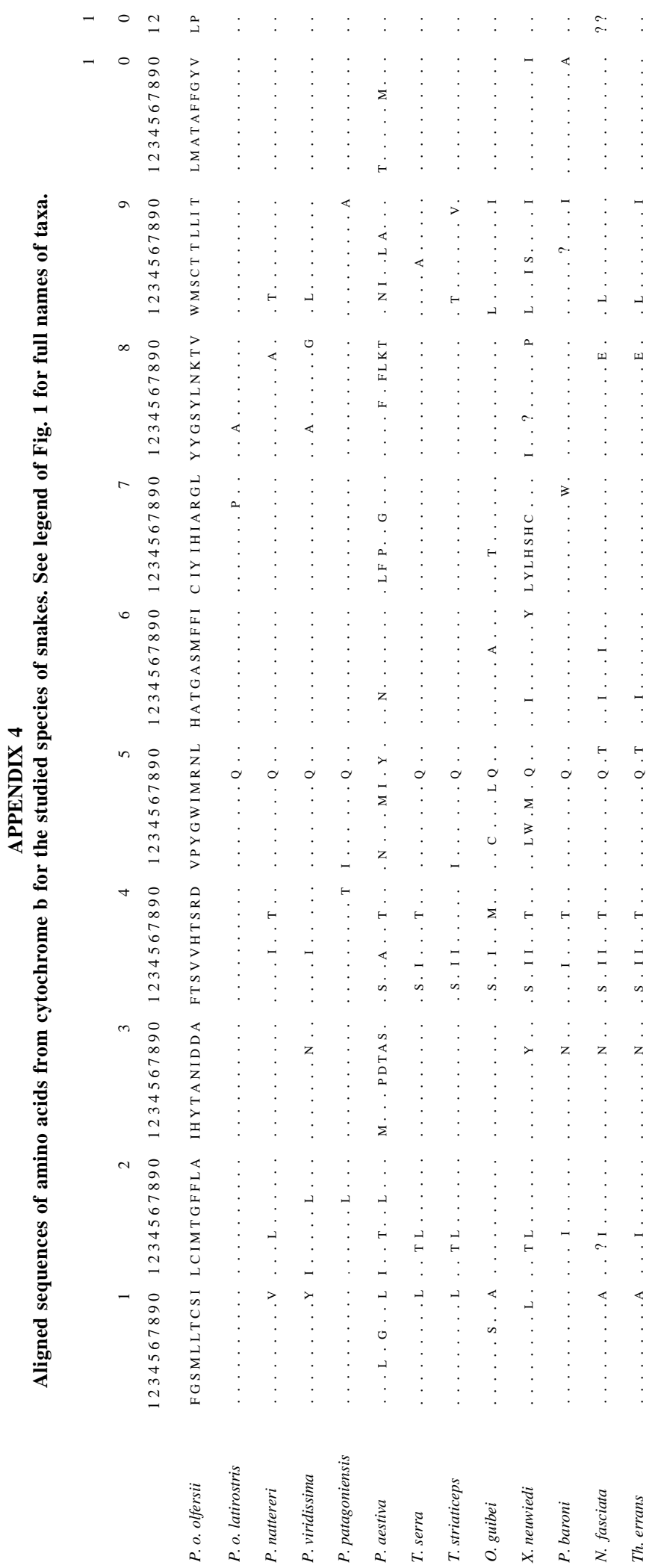


Acknowledgements - We are grateful for the help of Antônio Mateo Solé-Cava, Ivan Sazima, and Hector Seuanez for the supervision of this work when it was part of a Ph. D. thesis by the second author. Douglas Zeppelini read and provided suggestions on one version of the manuscript. Financial support was provided by Coordenação de Aperfeiçoamento de Pessoal de Nível Superior (CAPES) and Conselho Nacional de Desenvolvimento Científico e Tecnológico (CNPq).

\section{REFERENCES}

ABOUHEIF, E., ZARDOYA, R. \& MEYER, A., 1998, Limitations of metazoan 18S rRNA sequence data: Implications for reconstructing a phylogeny of the animal kingdom and inferring the reality of the Cambrian explosion. J. Mol. Evol., 47: 394-405.

BREMER, K., 1988, The limits of amino acid sequence data in angiosperm phylogenetic reconstruction. Evolution, 42: 795-803.

BROWN, W. M., GEORGE, M. Jr. \& WILSON, A. C., 1979, Rapid evolution of animal mitochondrial DNA. Proc. Natl. Acad. Sci. USA, 76: 1967-1971.

DE QUEIROZ, A. \& LAWSON, R., 1994, Phylogenetic relationships of the garter snakes based on DNA sequence and allozyme variation. Biol. J. Linn. Soc., 53: 209-229.

DREYER, H. \& WÄGELE, J. W., 2001, Parasites of crustaceans (Isopoda: Bopyridae) evolved from fish parasites; molecular and morphological evidence. Zoology, 103: 157-178.

FARRIS, J. S., 1969, A successive approximations approach to character weighting. Syst. Zool., 18: 374-385.

FELSENSTEIN, J., 1978, The number of evolutionary trees. Syst. Zool., 27: 27-33.

FELSENSTEIN, J., 1988, Phylogenies from molecular sequences: inference and reliability. Annu. Rev. Gen., 22: 521-565.

FERRAREZZI, H., 1994, Uma sinopse dos gêneros e classificação das Serpentes (Squamata): II. Family Colubridae, pp. 8191. In: L. B. Nascimento, A. Tristão \& G. A. Cotta (eds.), Herpetologia do Brasil 1. Fundação Biodiversitas e Fundação Ezequiel Dias, Belo Horizonte, Minas Gerais.

FITCH, W. M., 1971, Toward defining the course of evolution: minimum change for a specific tree topology. Syst. Zool., 20: 406-416.

FITCH, W. M., \& MARGOLIASH, E., 1967, Construction of phylogenetic trees. Science, 155: 279-284.

GATESY, J., DESALLE, R. \& WHEELER, W., 1993, Alignmentambiguous nucleotide sites and the exclusion of systematic data. Mol. Phylogenet. Evol., 2: 152-157.

GIRIBET, G. \& WHEELER, W. C., 1999, On gaps. Mol. Phylogenet. Evol., 13: 132-143.

GOLDMAN, N. \& YANG, Z., 1994, A codon-based model of nucleotide substitution for protein-coding DNA sequences. Mol. Biol. Evol., 11: 725-736.

IRWIN, D. M., KOCHER, T. D. \& WILSON, A. C., 1991, Evolution of the cytochrome b gene of mammals. J. Mol. Evol., 32: 128-144.
KOCHER, T. D., THOMAS, W. K., MEYER, A., EDWARDS, S. V., PAABO, S., VILLABLANCA, F. X. \& WILSON, A. C., 1989, Dynamics of mitochondrial DNA evolution in animals: amplification and sequencing with conserved primers. Proc. Natl. Acad. Sci. USA, 86: 6196-6200.

LAKE, J. A., 1991, The order of sequence alignment can bias the selection of tree topology. Mol. Biol. Evol., 8: 378-385.

LECOINTRE, G., PHILIPPE, H., VAN LÉ, H. L. \& LE GUYADER, H., 1993, Species sampling has a major impact on phylogenetic inference. Mol. Phylogenet. Evol., 2: 205224.

LI, W.-H.,1997, Molecular evolution. Sinauer, Sunderland, Massachusetts.

MALEY, L. E. \& MARSHALL, C. R., 1998, The coming of age of molecular systematics. Science, 279: 505-506.

McHUGH, D., 1998, Deciphering metazoan phylogeny: the need for additional molecular data. Amer. Zool., 38: 859-866.

MOORE, G. W., BARNABAS, J. \& GOODMAN, M., 1973, A method for constructing maximum parsimony ancestral amino acid sequences on a given network. J. Theor. Biol., 38: 459-485.

MOORE, G. W., GOODMAN, M. \& CALLAHAN, C., 1976, Stochastic versus augmented maximum parsimony method for estimating superimposed mutations in the divergent evolution of protein sequences. Methods tested on cytochrome c amino acid sequences. J. Mol. Biol., 105: 15-37.

MULLIS, K., FALOONA, F., SCHARF, S., SAKAI, R., HORN, G. \& ERLICH, H., 1986, Specific enzymatic amplification of DNA in vitro: the polymerase chain reaction. Cold Spring Harbor Symp. Quant. Biol., 51: 263-273.

NAYLOR, G. J. \& BROWN, W. M., 1998, Amphioxus mitochondrial DNA, chordate phylogeny, and the limits of inference based on comparisons of sequences. Syst. Biol., 47: 61-76.

NOWAK, R., 1994. Mining treasures from "junk DNA". Science, 363: 608-610

OTTO, S. P., CUMMINGS, M. P. \& WAKELEY, J., 1996, Inferring phylogenies from DNA sequence data: the effects of sampling, pp. 103-115. In: P. H. Harvey, A. J. L. Brown, J. M. Smith \& S. Nee (eds.), New uses for new phylogenies. Oxford Univ. Press, Oxford.

PATTERSON, C., 1988, Homology in classical and molecular biology. Mol. Biol. Evol., 5: 603-625.

PHILIPPE, H., CHENUIL, A. \& ADOUTTE, A., 1994, Can the Cambrian explosion be inferred through molecular phylogeny? Development, Suppl.: 15-25.

REMANE, A., 1961, Gedanken zum problem: homologie und analogie, praeadaptation und parallelität. Zool. Anz., 166: 447-465.

SIMMONS, C., FRATI, F., BECKENBACH, A., CRESPI, B., LIU, H. \& FLOOK, P., 1994, Evolution, weighting, and phylogenetic utility of mitochondrial gene sequences and a compilation of conserved polymerase chain reaction primers. Ann. Entomol. Soc. Am., 87: 651-701. 
SIMMONS, M. P., 2000, A fundamental problem with aminoacid-sequence characters for phylogenetic analyses. Cladistics, 16: 274-282.

SWOFFORD, D. L., 1998, PAUP*: Phylogenetic analysis using parsimony (*and other methods), version 4.0. Sinauer, Sunderland, Massachusetts.

SWOFFORD, D. L., OLSEN, G. J., WADDELL, P. T. \& HILLIS, D. M., 1996a, Phylogenetic inference, pp. 441-501. In: D. M. Hillis, M. Craig \& Mable, B. K. (eds.), Molecular systematics. 2nd edition, Sinauer, Sunderland, Massachusetts.

SWOFFORD, D. L., THORNE, J. L., FELSENSTEIN, J. \& WIEGMANN, B. M., 1996b, The topology-dependent permutation test for monophyly does not test for monophyly. Syst. Biol., 45: 575-579.

WÄGELE, J. W., 1994, Review of methodological problems of 'computer cladistics' exemplified with a case study on isopod phylogeny (Crustacea: Isopoda). Z. Zool. Syst. Evol.-forsch., 32: 81-107.
WÄGELE, J. W., 1999, Major sources of errors in phylogenetic systematics. Zool. Anz., 238: 329-337.

WÄGELE, J. W. \& RÖDDING, F., 1998, A priori estimation of phylogenetic information conserved in aligned sequences. Mol. Phylogen. Evol., 9: 358-365.

WÄGELE, J. W. \& STANJEK, G., 1995, Arthropod phylogeny inferred from partial $12 \mathrm{~S}$ rRNA revisited: monophyly of the Tracheata depends on sequence alignment. J. Zool. Evol. Res., 33: 75-80.

WÄGELE, J. W. \& WETZEL, R., 1994, Nucleic acid sequence data are not per se reliable for inference of phylogenies. $J$. Nat. Hist., 28: 749-761.

WHEELER, W. C., 1990, Nucleic acid sequence phylogeny and random outgroups. Cladistics, 6: 363-367.

WINNEPENNINCKX, B. \& BACKELJAU, T., 1996, 18S rRNA alignments derived from different secondary structure models can produce alternative phylogenies. J. Zool. Syst. Evol. Res., 34: 135-143. 